\title{
THE INFLUENCE OF DIFFERENT WATER AND NITROGEN APPLICATIONS ON SOME YIELD PARAMETERS AND ANTIOXIDANT ACTIVITY IN SAGE (Salvia officinalis L.)
}

\author{
Cigdem SONMEZ, Emine BAYRAM \\ Ege University, Faculty of Agriculture, Department of Field Crops, Izmir, TURKEY \\ ${ }^{*}$ Corresponding author:cigdemsnmz@gmail.com
}

Received: 20.02.2017

\begin{abstract}
The effect of different water and nitrogen applications on some yield parameters and antioxidant activity on sage (Salvia officinalis L. var. Extrakta) was investigated. A field trial was arranged in the split plot design with four replications under the Bornova ecological conditions in 2012 and 2013. The following water regimes were used as main plots: S1 (irrigated when it's needed), S2 (20 days dry before harvesting) and S3 (40 days dry before harvesting) and nitrogen applications were used as sub-plots such as $0 \mathrm{~kg} \mathrm{ha}^{-1}$ and $60 \mathrm{~kg} \mathrm{ha}^{-1}$. The following plant characteristics such as plant height $(\mathrm{cm})$, fresh herbage yield $\left(\mathrm{kg} \mathrm{ha}^{-1}\right)$, drug herbage yield $(\mathrm{kg}$ $\left.\mathrm{ha}^{-1}\right)$, drug leaf yield $\left(\mathrm{kg} \mathrm{ha}^{-1}\right)$, essential oil ratio (\%), essential oil yield, essential oil content (\%), antioxidant capacity $(\mu \mathrm{mol}$ FRAPgDM) were recorded. The highest essential oil ratio was obtained from the S3 water dose such as $\mathbf{2 . 0 7 \%}$. The main component in the essential oils recovered by both experiments were $\alpha+\beta$ thujone showing a large variation. Considering the $\mathrm{N}$ fertilization combined with the $\mathrm{S} 2$ irrigation had positive effect on the characteristics measured. It could be concluded that the antioxidant activity tended to increase as the soil moisture decreased.
\end{abstract}

Keywords: essential oil, nitrogen, sage, Salvia officinalis L., water application

\section{INTRODUCTION}

Environmental conditions play an active role in plant production. Abiotic stress such as drought, high temperature, soil salinity, chilling may decrease agricultural prolificacy. Plants can manage to survive under adverse circumstances with secondary metabolites. Water is also important in the growth and productivity of medical and aromatic plants similar to many cultivated plants. Especially water deficiency is important problem on medicinal and aromatic plants in growing season. Although lack of water reduced yield of aerial parts, it can enhanced accumulation of more metabolites to prevent from oxidization damage in plant tissues (Farahini et al., 2009; Bettaieb et al., 2011; Manukyan, 2011; Abdelmajeed et al., 2013). Salvia officinalis L. (sage) is one of the economically important species in Lamiaceae family that sage is a perennial woody sub-shrub and blue to purplish flowers. It is used for many purposes in ancient times. Leaves of Salvia officinalis L. are consumed in foods, drugs and perfumery industries and they have antioxidative properties. Additionally, other significant effects are antibacterial, fungistatic, virustatic, astringent, hypoglycemic and cytotoxic activities (Bernotiene et al., 2007; Bettaieb et al., 2009; Zervoudakis et al., 2012; Corell et al., 2012; Porte et al., 2013; Tosun et al., 2014; Said-Al Ahl et al., 2015). Salvia officinalis L. is native to the Mediterranean region and sage is cultivated in several countries but it is not widely found in the Turkish natural flora. It can easily grow in the western coast of Anatolia.

The aim of this study was to investigate the effect of irrigation arrangements and nitrogen applications on herbal yield, quantity of essential oils and antioxidant capacity of Salvia officinalis L. under the field conditions in the Mediterranean climate zone of Turkey.

\section{MATERIALS AND METHODS}

The field experiment was conducted in 2012 and 2013 in the Department of Field Crops, Faculty of Agriculture, Ege University, located at Bornova-İzmir. The temperature, rainfall and humidity of the growing years are shown in Table 1. The mean annual temperature was 18.6 and $18.5^{\circ} \mathrm{C}$, and the total annual precipitation was 799.3 and $854.7 \mathrm{~mm}$ in 2012 and 2013, respectively. 
Table 1. Some meteorological parameters of experimental site at Bornova in 2012-2013 (Anonymus 2012 and 2013)

\begin{tabular}{|c|c|c|c|c|c|c|}
\hline \multirow[b]{2}{*}{ Month } & \multicolumn{3}{|c|}{2012} & \multicolumn{3}{|c|}{2013} \\
\hline & $\begin{array}{c}\text { Mean } \\
\text { Temperature } \\
\left({ }^{\circ} \mathrm{C}\right)\end{array}$ & $\begin{array}{c}\text { Total } \\
\text { Rainfall } \\
(\mathbf{m m})\end{array}$ & $\begin{array}{c}\text { Relative } \\
\text { Humidity } \\
(\%)\end{array}$ & $\begin{array}{c}\text { Mean } \\
\text { Temperature } \\
\left({ }^{\circ} \mathrm{C}\right)\end{array}$ & $\begin{array}{c}\text { Total } \\
\text { Rainfall } \\
(\mathrm{mm})\end{array}$ & $\begin{array}{c}\text { Relative } \\
\text { Humidity } \\
(\%)\end{array}$ \\
\hline January & 6.8 & 127.7 & 67.6 & 9.4 & 252.5 & 70.9 \\
\hline February & 7.6 & 128.2 & 66.9 & 11.2 & 187 & 70.2 \\
\hline March & 11.3 & 34.7 & 57.8 & 14 & 56.8 & 58.5 \\
\hline April & 17.5 & 105 & 58.8 & 17.3 & 30.2 & 54 \\
\hline May & 20.5 & 86.6 & 62.9 & 22.7 & 43.7 & 54.7 \\
\hline June & 27.3 & 19.9 & 48.5 & 25.7 & 27.1 & 50.7 \\
\hline July & 30.1 & 0 & 45.2 & 28.4 & 0 & 42 \\
\hline August & 29.2 & 0 & 39.5 & 28.7 & 20.2 & 45.1 \\
\hline September & 24.3 & 0 & 55.4 & 24 & 5.1 & 48.7 \\
\hline October & 21.7 & 22.1 & 59.5 & 17.2 & 94.1 & 60.8 \\
\hline November & 16.4 & 56.9 & 65 & 15 & 128.9 & 70 \\
\hline December & 10.7 & 218.2 & 71.4 & 8.5 & 9.1 & 59.3 \\
\hline mean-total & 18.6 & 799.3 & 58.2 & 18.5 & 854.7 & 57.1 \\
\hline
\end{tabular}

The soil texture was classified as clayey-loamy and $\mathrm{pH}: \quad 7.8$ in $20-40 \mathrm{~cm}$ soil depth. A summary of soil chemical 8.7 in soil surface, it was classified as clayey-sandy, $\mathrm{pH}$ : properties was presented in Table 2 .

Table 2. Some physical and chemical characteristics of the soils of the experimental site (Sonmez and Bayram, 2009)

\begin{tabular}{llllllllllll}
\hline $\begin{array}{c}\text { Soil } \\
\text { depth }\end{array}$ & Sand & Silt & Clay & $\mathbf{N}(\%)$ & $\mathbf{P}(\mathbf{p p m})$ & $\mathbf{K}(\mathbf{p p m})$ & $\mathbf{C a}(\mathbf{p p m})$ & $\mathbf{N a}(\mathbf{p p m})$ & $\mathbf{F e}(\mathbf{p p m})$ & $\begin{array}{c}\mathbf{O M}^{\mathbf{a}} \\
(\boldsymbol{\%})\end{array}$ & $\mathbf{p H}$ \\
\hline $\begin{array}{c}0-20 \\
\mathrm{~cm}\end{array}$ & 24.72 & 32.56 & 42.72 & 0.101 & 0.4 & 400 & 5400 & 20 & 13.6 & 1.130 & 8.2 \\
$\begin{array}{c}20-40 \\
\mathrm{~cm}\end{array}$ & 32.72 & 30.56 & 36.72 & 0.123 & 0.4 & 300 & 5100 & 20 & 16.2 & 1.150 & 7.8 \\
\hline
\end{tabular}

The seeds of Salvia officinalis L. var. Extrakta obtained from in Germany were sown into a mixture of sand, manure and mulch $(1: 1: 1)$ on November 22,2010 . When the sage seedlings reached about $10 \mathrm{~cm}$ in plant height, they were transferred to the experimental plots on April 4, 2011. The field trial was arranged in two-factor split-plot experimental design with four replications. Experimental factors were water regimes of main plot: S1 (irrigated when it is needed), S2 (20 days dry before harvesting) and S3 (40 days dry before harvesting) and the nitrogen applications were used as sub-plots $\left(0 \mathrm{~kg} \mathrm{ha}^{-1}\right.$ and $\left.60 \mathrm{~kg} \mathrm{ha}^{-1}\right)$. Nitrogen as ammonium sulphate was applied in two equal splits, at one split spring and other after the first cutting in two years. Each plot consisted of six rows with a $3 \mathrm{~m}$ length and 40 $\mathrm{cm} \times 20 \mathrm{~cm}$ of plant spacing. Total amount of water application (dripping irrigation) was measured by flow meter for each irrigation traits in the dry seasons. Table 3. gives detailed information about the experiment.

Table 3. Irrigation traits during the dry seasons of total water content applications (mm)

\begin{tabular}{cccc}
\hline \multirow{2}{*}{ Years } & \multicolumn{3}{c}{ Irrigation arrangements } \\
& S1 & S2 & S3 \\
\hline $\mathbf{2 0 1 2}$ & 875 & 426 & 198 \\
$\mathbf{2 0 1 3}$ & 855 & 415 & 210 \\
\hline
\end{tabular}

Three controlled irrigation applications were started on April 27, 2012 and April 262013 in dry season beginning.
The dates of the harvest were June 6 and September 17 in 2012 and June 6 and September 4 in 2013. The side effect was eliminated and the following characteristics were measured:

Plant height $(\mathrm{cm})$ : The plant was measured from the soil surface to the top level of the plant before each harvest.

Fresh herbage yields ( $\left.k g h a^{-1}\right)$ : The plants were harvested by hand with a saw knife, $10 \mathrm{~cm}$ above the surface, and immediately weighed for the obtained plot yields. Then the plot yield was converted to a yield for a hectare.

Drug herbage yields $\left(\mathrm{kg} \mathrm{ha}^{-1}\right)$ : A sample of $500 \mathrm{~g}$ of green herb was taken from each plot. The samples were dried at $35{ }^{\circ} \mathrm{C}$ for $72 \mathrm{~h}$ to determine its dry weight.

Drug leaf yields $\left(\mathrm{kg} \mathrm{ha}^{-1}\right)$ : A sample of $500 \mathrm{~g}$ green herbs was taken from each plot. The leaves of the samples were separated from the stems by hand and weighed. The leaves were dried in an oven at $35{ }^{\circ} \mathrm{C}$ for $72 \mathrm{~h}$ to determine the dry weight.

Essential oil content (\%): Dry leaf materials of $10 \mathrm{~g}$ were subjected to a $3 \mathrm{~h}$ water-distillation using a NeoClevenger apparatus, and the extracted essential oils were stored at $4{ }^{\circ} \mathrm{C}$ until the gas chromatography (GC) analysis. The essential oil ratios of the plants were determined by a volumetric method (ml/100 g) (Wichtl, 1971). 
Composition of the essential oil (\%): The gas chromatography (GC) analysis for essential oil compounds was performed using an Agilent $6890 \mathrm{~N}$ chromatograph, equipped with flame-ionization detection (GC-FID). The compounds were separated on a $30 \mathrm{~m} \times 0.25 \mathrm{~mm}, 0.25 \mu \mathrm{m}$ film thickness, DB-Wax capillary column, with helium as a carrier gas at a constant flow rate of $1 \mathrm{~mL} / \mathrm{min}$. The oven temperature program was $45{ }^{\circ} \mathrm{C}(2 \mathrm{~min}), 45-250{ }^{\circ} \mathrm{C}$ $(3 \% \mathrm{~min}), 250{ }^{\circ} \mathrm{C}(34 \mathrm{~min})$, and the injector and detector temperatures were $250{ }^{\circ} \mathrm{C}$. The identification of the components was based on the comparison of their relative retention times (RT) with those from the authentic standards found in the laboratory.

Antioxidant activity ( $\mu$ mol FRAPgDM): The analysis of antioxidant capacity by Ferric Reducing Antioxidant Power (FRAP) was conducted in accordance with Benzie and Strain (1999). Dry leaves $(0.5 \mathrm{~g})$ were ground with $20 \mathrm{~mL}$ $80 \%(\mathrm{v} / \mathrm{v})$ ethanol and then centrifuged for $20 \mathrm{~min}$ at $4{ }^{\circ} \mathrm{C}$. The reaction was started by adding $0.05 \mathrm{~mL}$ extract to 1.50 $\mathrm{mL}$ FRAP reagent and $0.15 \mathrm{~mL}$ distilled water. The absorbance of the reaction mixture was measured spectrophotometrically (Cary 50®) at $593 \mathrm{~nm}$. The results were expressed as $\mu$ moles FRAP in $1 \mathrm{~g}$ dry matter.

Statistical analysis: All data were statistically analyzed using the TOTEMSTAT Statistical program (Acikgoz et al., 2004). The treatment means were compared by using the LSD test as described by Steel and Torrie (1980).

\section{RESULTS AND DISCUSSION}

The result of plant height was summarized in Table 4 . In general, the plant height was affected significantly by irrigation applications and nitrogen doses. According to general average the highest plant height was obtained during S1 application as $48.91 \mathrm{~cm}$ and nitrogen application increased the plant height in 2012. In second year, not only $\mathrm{S} 1$ and $\mathrm{S} 2$ irrigation treatments but also nitrogen application incerased the plant height. For both study years, the average mean of the plant heights decreased significantly with decreasing of water amount and without nitrogen. Analysis of data collected during two years revealed that plant height increased significantly and positively with irrigation frequency and nitrogen doses.

Table 4. Influence of irrigation treatments and nitrogen doses on Salvia officinalis L. var. Extrakta plant height in 2012 and 2013 (cm)

\begin{tabular}{|c|c|c|c|c|c|c|c|c|c|c|c|c|}
\hline \multicolumn{13}{|c|}{2012} \\
\hline \multirow{3}{*}{$\begin{array}{l}\text { N App. } \\
\left(\mathrm{kg} \mathrm{ha}^{-1}\right)\end{array}$} & \multicolumn{4}{|c|}{ 1st cutting } & \multicolumn{4}{|c|}{ 2nd cutting } & \multicolumn{4}{|c|}{ Average } \\
\hline & \multicolumn{9}{|c|}{ Irrigation Applications } & & & \\
\hline & S1 & S2 & S3 & Mean & S1 & $\mathrm{S} 2$ & S3 & Mean & S1 & S2 & S3 & Mean \\
\hline 0 & 56.65 & 47.35 & 48.4 & $50.80^{\mathrm{b}}$ & 34.6 & 30.5 & 26.28 & 30.46 & 45.63 & 38.93 & 37.34 & $40.63^{\mathrm{b}}$ \\
\hline 60 & 70.25 & 64.83 & 61.1 & $65.39^{\mathrm{a}}$ & 34.13 & 31.1 & 27.83 & 31.02 & 52.19 & 47.96 & 44.46 & $48.20^{\mathrm{a}}$ \\
\hline Mean & 63.45 & 56.09 & 54.75 & & $34.36^{\mathrm{a}}$ & $30.8^{\mathrm{b}}$ & $27.05^{\mathrm{c}}$ & & $48.91^{\mathrm{a}}$ & $43.44^{\mathrm{b}}$ & $40.90^{\mathrm{b}}$ & \\
\hline LSD & & $\mathrm{I}=\mathrm{ns}$ & & $\mathrm{N}=7.63 * *$ & & $\mathrm{I}=2.92 * *$ & & $\mathrm{~N}=\mathrm{ns}$ & & $\mathrm{I}=5.27 *$ & & $\mathrm{~N}=7.63 * *$ \\
\hline & & & & & & 2013 & & & & & & \\
\hline 0 & 50.9 & 52.63 & 50.25 & $51.25^{\mathrm{b}}$ & $29.35^{\mathrm{bc}}$ & $27.2^{\mathrm{c}}$ & $21.7^{\mathrm{d}}$ & 26.08 & 40125 & 39.91 & 35.97 & $38.67 b$ \\
\hline 60 & 61.55 & 59.2 & 53.45 & $58.06^{\mathrm{a}}$ & $34.05^{\mathrm{a}}$ & $30.25^{\mathrm{b}}$ & $22.5^{\mathrm{d}}$ & 28.93 & 47.8 & 44.72 & 37.97 & $43.50^{\mathrm{a}}$ \\
\hline Mean & 56.23 & 55.91 & 51.85 & & 31.7 & 28.73 & 22.1 & & $43.96^{\mathrm{a}}$ & $42.32^{\mathrm{a}}$ & $36.98^{\mathrm{b}}$ & \\
\hline LSD & $\mathrm{N}=\mathrm{ns}$ & & & $\mathrm{I}=4.88 * *$ & & $\mathrm{NxI}=$ & $.90 *$ & & & $\mathrm{~N}=4.76$ * & & $\mathrm{I}=2.93 * *$ \\
\hline
\end{tabular}

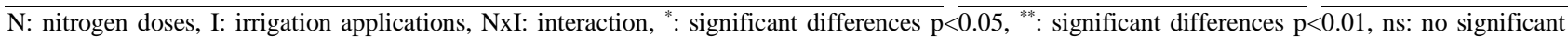
differences

When both cutting and annual general averages for the 2012 and 2013 years of this study were examined, it was determined that the nitrogen application increased the plant height. The increase of water restriction before the harvest caused to decrease of plant height values. According to the comparison of the first cutting and the second cutting of the research years, the highest of plant height was observed in first cutting, it is considered to be the effect of the winter and spring rains before the irrigations treatments. Many researchers (Koc, 2000; Ozturk et al., 2004; Oktay Koc., 2006; Ipek, 2007; Bettaieb et al., 2009; Ekren et al., 2011; Fathi et al., 2012; Bahreininejad et al., 2013) reported similar result on Salvia officinalis L. and members of Lamiaceae family, too.
The irrigation treatment $\mathrm{x}$ applying nitrogen interaction affected the fresh herbage yield significantly $(\mathrm{p}<0.01)$ in 2012 and 2013 (Table 5). The maximum fresh herbage yield (43073.9-39827.5 $\mathrm{kg} \mathrm{ha}^{-1}$ ) were observed in plots which received S1 (irrigated when it's needed) with $60 \mathrm{~kg}$ $\mathrm{ha}^{-1}$ of nitrogen fertilizer. It can be said that interactions of $\mathrm{S} 2 \times 60 \mathrm{~kg} \mathrm{ha}^{-1} \mathrm{~N}$ in both year's and $\mathrm{S} 1 \times 0 \mathrm{~kg} \mathrm{ha}^{-1} \mathrm{~N}$ in the first year at second harvest and each harvest in the second year's values had second higher fresh herbage yields. Also, the treatment of S3 with no fertilizer application had the lowest fresh herbage yield. This can be related to the fact that nitrogen fertilizer and soil moisture improve soil physical and chemical properties which are effective on vegetative growth. 
Table 5. Influence of irrigation treatments and nitrogen doses on Salvia officinalis L. var. Extrakta fresh herbage yield in 2012 and $2013\left(\mathrm{~kg} \mathrm{ha}^{-1}\right)$

\begin{tabular}{|c|c|c|c|c|c|c|c|c|c|c|c|c|}
\hline \multicolumn{13}{|c|}{2012} \\
\hline $\mathrm{N}$ & \multicolumn{4}{|c|}{ 1st cutting } & \multicolumn{4}{|c|}{ 2nd cutting } & \multicolumn{4}{|c|}{ Total Yield } \\
\hline \multirow{2}{*}{$\begin{array}{l}\text { App. } \\
\left(\begin{array}{c}\mathrm{kg} / \mathrm{ha}^{-} \\
1\end{array}\right)\end{array}$} & \multicolumn{12}{|c|}{ Irrigation Applications } \\
\hline & S1 & S2 & S3 & Mean & S1 & S2 & S3 & Mean & S1 & S2 & S3 & Mean \\
\hline 0 & $15482.0^{\mathrm{c}}$ & $13921.3^{\mathrm{d}}$ & $11361.2^{\mathrm{f}}$ & 13588.2 & $14369.0^{\mathrm{b}}$ & $10900.8^{\mathrm{c}}$ & $8408.7^{\mathrm{e}}$ & 11226.2 & $29851.0^{\mathrm{c}}$ & $24822.1^{\mathrm{d}}$ & $19769.8^{f}$ & 24814.3 \\
\hline 60 & $22356.4^{\mathrm{a}}$ & $18762.0^{\mathrm{b}}$ & $12740.4^{\mathrm{e}}$ & 17952.9 & $20717.5^{\mathrm{a}}$ & $14462.1^{\mathrm{b}}$ & $9964.5^{\mathrm{d}}$ & 15048.1 & $43073.9^{\mathrm{a}}$ & $33224.1^{\mathrm{b}}$ & $22704.9^{\mathrm{e}}$ & 33001.0 \\
\hline Mean & 15482.0 & 13921.3 & 11361.2 & 13588.2 & 17543.2 & 12681.5 & 9186.6 & & 36462.4 & 29023.1 & 21237.4 & \\
\hline LSD & \multicolumn{4}{|c|}{$\mathrm{NxI}=839.7 * *$} & \multicolumn{4}{|c|}{$\mathrm{NxI}=1380.7 * *$} & \multicolumn{4}{|c|}{$\mathrm{NxI}=1546.7 * *$} \\
\hline \multicolumn{13}{|c|}{2013} \\
\hline 0 & $15336.5^{\mathrm{b}}$ & $12451.9^{c}$ & $8527.6^{\mathrm{d}}$ & 12105.4 & $13421.3^{b}$ & $9230.8^{\mathrm{c}}$ & $6845.0^{\mathrm{d}}$ & 9832.3 & $28757.8^{b}$ & $21682.7^{\mathrm{c}}$ & $15372.6^{\mathrm{e}}$ & 21937.7 \\
\hline 60 & $21111.8^{\mathrm{a}}$ & $16436.3^{\mathrm{b}}$ & $10751.2^{\mathrm{c}}$ & 16099.8 & $18715.7^{\mathrm{a}}$ & $11706.7^{\mathrm{b}}$ & $8381.0^{\mathrm{cd}}$ & 12934.5 & $39827.5^{\mathrm{a}}$ & $28143.0^{\mathrm{b}}$ & $19132.2^{\mathrm{d}}$ & 29034.3 \\
\hline Mean & 18224.2 & 14444.1 & 9639.4 & & 16068.5 & 10468.8 & 7613.0 & & 34292.7 & 24912.9 & 17252.4 & \\
\hline LSD & \multicolumn{4}{|c|}{$\mathrm{NxI}=1822.1 * *$} & \multicolumn{4}{|c|}{$\mathrm{NxI}=1788.5^{* *}$} & \multicolumn{4}{|c|}{$\mathrm{NxI}=2296.5 * *$} \\
\hline
\end{tabular}

Several studies showed that nitrogen application enhanced biomass on Salvia officinalis L. plants of aerial parts (Ceylan et al., 1979; Putievsky et al., 1986; Ceylan et al., 1994; Koc, 2000; Oktay Koc, 2006; Ipek, 2007) until critical dosage. Bettaieb et al. (2009) investigated different irrigation water levels $\left(\mathrm{I}_{100}: 100 \%, \mathrm{I}_{50}: 50 \%\right.$ and $\mathrm{I}_{25}: 25 \%$ of field capacity) on Salvia officinalis L. They found that fresh biomass increasingly correlated with amount of soil water so finds that the amount of soil water enhanced plant biomass. In other study, Bettaieb et al. (2011) determined the effect of water deficit (moderate and severe water deficits) on sage plant. Their result show that increasing in water scarcity led to the reduced production of fresh weight. Lier (1999) point out that water deficit can affect related to growth properties and water deficits cause to close stomata and limit the photosynthesis. So the most significant general effects of water deficiency are the reduction in plant size, leaf area, and crop yield. Fresh herbage yield was ascended by diminishing of irrigation interval and applying of nitrogen fertilizer in our research. In the presented study, it can be claimed that our result is harmonies in the light of these literatures.

The result of drug herbage yield was shown in Table 6 . Irrigation $\mathrm{x}$ nitrogen applications interaction recorded significantly higher drug herbage yield of $11629.0 \mathrm{~kg} \mathrm{ha}^{-1}$ S1x60 kg ha ${ }^{-1}$ as compared to the rest of the combination in first year of total yield. Before harvesting, 40 days dry treatment coupled with no nitrogen application resulted in the lowest drug herbage yield $\left(6503.2 \mathrm{~kg} \mathrm{ha}^{-1}\right)$. Various irrigation intervals had highly significant effect $(\mathrm{p}<0.01)$ on drug herbage yield in 2013. The maximum drug herbage yield was obtained from S1 applications as $10178.9 \mathrm{~kg} \mathrm{ha}^{-}$ ${ }^{1}$. It also evident from data that drug herbage yield was affected $(\mathrm{p}<0.01)$ by nitrogen. Nitrogen was increased total yield as $10175.6 \mathrm{~kg} \mathrm{ha}^{-1}$.

Table 6. Influence of irrigation treatments and nitrogen doses on Salvia officinalis L. var. Extrakta drug herbage yield in 2012 and $2013\left(\mathrm{~kg} \mathrm{ha}^{-1}\right)$

\begin{tabular}{|c|c|c|c|c|c|c|c|c|c|c|c|c|}
\hline \multicolumn{13}{|c|}{2012} \\
\hline \multirow{3}{*}{$\begin{array}{l}\text { N App. } \\
\left(\mathrm{kg} \mathrm{ha}^{-1}\right)\end{array}$} & \multicolumn{4}{|c|}{ 1st cutting } & \multicolumn{4}{|c|}{ 2nd cutting } & \multicolumn{4}{|c|}{ Total Yield } \\
\hline & \multicolumn{8}{|c|}{ Irrigation Aplications } & & & & \\
\hline & S1 & S2 & S3 & Mean & S1 & S2 & S3 & Mean & S1 & S2 & S3 & Mean \\
\hline 0 & $3731.7^{\mathrm{c}}$ & $3775.9^{\mathrm{c}}$ & $3238.4^{\mathrm{d}}$ & 3582.0 & $3947.6^{\text {cd }}$ & $3620.9^{\mathrm{de}}$ & $3264.8^{\mathrm{e}}$ & 3611.1 & $7679.3^{\mathrm{c}}$ & $7396.8^{c}$ & $6503.2^{\mathrm{d}}$ & 7193.1 \\
\hline 60 & $5676.5^{\mathrm{a}}$ & $5284.7^{\mathrm{b}}$ & $3755.6^{\mathrm{c}}$ & 4905.6 & $5952.5^{\mathrm{a}}$ & $5080.0^{\mathrm{b}}$ & $4299.2^{\mathrm{c}}$ & 5110.6 & $11629.0^{\mathrm{a}}$ & $10364.7^{\mathrm{b}}$ & $8054.9^{c}$ & 10016.2 \\
\hline Mean & 4704.1 & 4530.3 & 3497.0 & & 4950.0 & 4350.4 & 3782.0 & & 9654.2 & 8880.7 & 7279.0 & \\
\hline LSD & \multicolumn{4}{|c|}{$\mathrm{NxI}=352.5^{* *}$} & \multicolumn{4}{|c|}{$\mathrm{NxI}=429.9^{*}$} & \multicolumn{4}{|c|}{$\mathrm{NxI}=664.0 * *$} \\
\hline \multicolumn{13}{|c|}{2013} \\
\hline 0 & 4548.4 & 4267.4 & 3251.0 & $4022.3^{b}$ & 3820.2 & 3574.2 & 3021.4 & $3471.9^{b}$ & 8368.7 & 7841.6 & 6272.4 & $7494.2^{b}$ \\
\hline 60 & 6487.9 & 5659.0 & 4300.4 & $5482.4^{\mathrm{a}}$ & 5501.2 & 4565.3 & 4013.1 & $4693.2^{\mathrm{a}}$ & 11989.1 & 10224.3 & 8313.5 & $10175.6^{\mathrm{a}}$ \\
\hline Mean & $5518.2^{\mathrm{a}}$ & $4963.2^{\mathrm{a}}$ & $3775.7^{b}$ & & $4660.7^{\mathrm{a}}$ & $4069.8^{b}$ & $3517.2^{c}$ & & $10178.9^{a}$ & $9032.9^{b}$ & $7293.0^{c}$ & \\
\hline LSD & $\mathrm{I}=661.9 *$ & & & $\mathrm{~N}=681.9^{* *}$ & $\mathrm{I}=403.2 *$ & & & $\mathrm{~N}=479.5^{* *}$ & $\mathrm{I}=624.4 * *$ & & & $\mathrm{~N}=1009.4 * *$ \\
\hline
\end{tabular}

$\mathrm{N}$ : nitrogen doses, I: irrigation applications, NxI: interaction, ${ }^{* *}$ : significant differences $\mathrm{p}<0.01$

Ceylan et al. (1994) studied the effect of nitrogen doses on sage and they found that drug herbage yield varied from 5580 to $7130 \mathrm{~kg} \mathrm{ha}^{-1}$. Koc (2000) mentioned that increasing of nitrogen quantities enhanced the drug herbage yields. Khalil et al. (2008) reported the same results on sage. Bettaieb et al. (2009) found that the increases in water deficiency affected negatively the amount of drug herbage in sage. Many studies showed production of aerial parts of Lamieceae member plants related with water volumes. Water deficiency in soil reduced the drug herbage yield
(Arabaci, 1995; Baher et al. 2002; Ozturk et al. 2004; Bettaieb et al. 2009; Farahani et al.2009; Ekren et al. 2012; Bahreininejad et al. 2013). This could be a result of reduction in the chlorophyll content and photosynthesis activity. The result of this study was generally in agreement with the ones reported by Arabaci. (1995); Baher et al. (2002); Ozturk et al. (2004); Farahani et al. (2009); Ekren et al. (2012); Bahreininejad et al. (2013). Our dry herbage yield values were higher than the values reported by Ceylan et al. (1994); Koc, (2000) and Khalil et al. (2008) because 
of different climate, environmental factors and the homogeneous material used in this research.

The yields of drug leaf yields of different nitrogen and water applications for 2012 and 2013 are evaluated statistically and the results of analysis are shown in Table 7. Interaction between two factors was found significant for drug leaf yields in 2012. The annual total leaf yield data are statistically important, it was determined that the S1 water treatment with nitrogen application had the highest drug leaf yield as $8123.5 \mathrm{~kg} \mathrm{ha}^{-1}$. In terms of total drug leaf yield main effect of irrigations intervals and nitrogen levels have showed great variations at $\mathrm{p}<0.01$ in 2013. The highest drug leaf yields were observed from S1 water treatments as $7662.9 \mathrm{~kg} \mathrm{ha}$. Nitrogen fertilizer application was increased total drug leaf yield as7631.4 $\mathrm{kg} \mathrm{ha}^{-1}$.

Table 7. Influence of irrigation treatments and nitrogen doses on Salvia officinalis L. var. Extrakta drug leaf yields in 2012 and 2013 $\left(\mathrm{kg} \mathrm{ha}^{-1}\right)$

\begin{tabular}{lcccccccccccc}
\hline \multicolumn{10}{c}{ 2012 } \\
\hline \multirow{8}{*}{$\begin{array}{c}\text { N App. } \\
\left(\mathrm{kg} \mathrm{ha}^{-1}\right)\end{array}$}
\end{tabular}

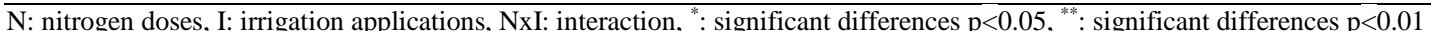

Baher et al. (2002) and Khazaie et al. (2008) stated in different research that reduction of irrigation frequency induced to decline vegetative yield components such as drug leaf yield. Farahani et al. (2009) and Atallah et al. (2010) who reported that the increase in water restriction resulted in a decrease in the yield of drug leaf yield. Researchers have obtained that there is a linear relationship between the increase of the soil moisture and the drug leaf yield. Fathi et al. (2012) found that Salvia sclarea L. has the highest values of leaf yield, flower yield and leaf area irrigated with 3 days intervals. The findings of the study were found similar trends with those reported by Baher et al. (2002); Khazaie et al. (2008); Farahani et al. (2009); Atallah et al. (2010); Fathi et al. (2012).

The essential oil ratio was given Table 8 . The interaction between water treatment and nitrogen fertilizer significantly affected average of essential oil content in 2012. The highest average essential oil content of Salvia officinalis L. var. Extrakta was obtained from S3 x $60 \mathrm{~kg}$ $\mathrm{ha}^{-1}$ application as $1.96 \%$. Second higher value was found from same irrigation application without nitrogen as $1.74 \%$. In 2013 growing season, the effects of different irrigation intervals with $\mathrm{N}$ applications were significant on essential oil ratio at $1 \%$ probability level. The treatments of water applications of general average had higher essential oil content as 2.07 and $1.97 \%$, respectively, S3 and S2 treatment were in the same statistical group. Essential oil rate increased with decreasing in irrigation level. In other words, volatile oil accumulation was positively affected by low soil moisture.
The chemical composition of the essential oil was obtained by GC from sage leaves. The data are shown in Table 9. $\alpha$-thujone was a dominant compound (25.09$34.33 \%)$ followed by camphor (15.16-34.59\%), $\beta$-thujone $(5.23-12.58 \%)$ and 1.8 -cineole $(2.85-9.48 \%)$ both harvests in 2012. Minor components including borneol (2.54$6.90 \%)$ and linalool (2.24-5.72\%) were also detected. In the second year, the leaf essential oil of Salvia officinalis L. plants showed that main constituents were not changed but represented different quantities. The findings indicate that $\alpha$-thujone was determined between 14.00 and $36.17 \%$. The other significant compound, camphor, was varied from $18.00 \%$ to $28.87 \%$. $\beta$-thujone (3.86-9.01\%) and 1.8 -cineole $(0-6.40 \%)$ were also detected, however their values found to be less than the amount detected in the previous year. Bettaieb et al. (2009) reported that there is no information about how it is affected main constitutes by water deficiency on Salvia officinalis L. and variations of $\alpha$ thujone, $\beta$-thujone and camphor were not clear about restriction of water treatment. Also, Azizi et al. (2009) stated that it is difficult to fully explain the effects of essential oils components of the water restrictions. The different water regimes altered the content of some essential oil components. Major constituents were found in different amounts such as $\alpha$-thujone (32.10-\%42.72), camphor (13.93-17.09\%), ß-thujone (8.62-16.17\%), 1.8 cineole (4.11-7.97\%) and borneol (1.62-2.60\%). In the presented study, major compounds were the same as the literatures although amount of basic components were variable in water treatments on Salvia officinalis L. plants. 
Table 8. Influence of irrigation treatments and nitrogen doses on Salvia officinalis L. var. Extrakta essential oil content in 2012 and $2013(\%)$

\begin{tabular}{|c|c|c|c|c|c|c|c|c|c|c|c|c|}
\hline \multicolumn{13}{|c|}{2012} \\
\hline \multirow{3}{*}{$\begin{array}{l}\text { N App. } \\
\left(\mathrm{kg} \mathrm{ha}^{-1}\right)\end{array}$} & \multicolumn{4}{|c|}{ 1st cutting } & \multicolumn{4}{|c|}{ 2nd cutting } & \multicolumn{3}{|c|}{ Average } & \\
\hline & \multicolumn{9}{|c|}{ Irrigation Aplications } & & & \\
\hline & S1 & S2 & S3 & Mean & S1 & S2 & S3 & Mean & S1 & S2 & S3 & Mean \\
\hline 0 & $1.69^{\mathrm{d}}$ & $2.15^{b}$ & $2.2^{\mathrm{a}}$ & 2.01 & 1.29 & 1.23 & 1.29 & 1.27 & $1.49^{\mathrm{d}}$ & $1.69^{\mathrm{bc}}$ & $1.74^{\mathrm{b}}$ & 1.64 \\
\hline 60 & $1.9^{\mathrm{c}}$ & $1.98^{\mathrm{bc}}$ & $2.35^{\mathrm{a}}$ & 2.08 & 1.51 & 1.45 & 1.58 & 1.51 & $1.71^{\mathrm{b}}$ & $1.71^{\mathrm{b}}$ & $1.96^{\mathrm{a}}$ & 1.79 \\
\hline Mean & 1.79 & 2.06 & 2.28 & & 1.40 & 1.34 & 1.43 & & 1.60 & 1.70 & 1.85 & \\
\hline LSD & \multicolumn{4}{|c|}{$\mathrm{NxI}=0.199 * *$} & \multicolumn{3}{|c|}{$\mathrm{I}=0.063^{*}$} & $\mathrm{~N}=0.105 * *$ & \multicolumn{4}{|c|}{$\mathrm{NxI}=0.095 *$} \\
\hline \multicolumn{13}{|c|}{2013} \\
\hline 0 & 1.99 & 2.05 & 2.30 & $2.11^{b}$ & 1.41 & 1.60 & 1.71 & 1.58 & 1.70 & 1.83 & 2.01 & $1.85^{b}$ \\
\hline 60 & 2.03 & 2.61 & 2.61 & $2.42^{\mathrm{a}}$ & 1.60 & 1.59 & 1.63 & 1.60 & 1.81 & 2.10 & 2.12 & $2.01^{\mathrm{a}}$ \\
\hline Mean & $2.01^{\mathrm{b}}$ & $2.33^{\mathrm{a}}$ & $2.46^{\mathrm{a}}$ & & 1.51 & 1.59 & 1.67 & & $1.76^{\mathrm{b}}$ & $1.97^{\mathrm{a}}$ & $2.07^{\mathrm{a}}$ & \\
\hline LSD & \multicolumn{3}{|c|}{$\mathrm{I}=0.300 * *$} & $\mathrm{~N}=0.255^{*}$ & $\mathrm{I}=\mathrm{ns}$ & & & $\mathrm{N}=\mathrm{ns}$ & $\mathrm{I}=0.1$ & $49^{* *}$ & & $\mathrm{~N}=0.142 *$ \\
\hline
\end{tabular}

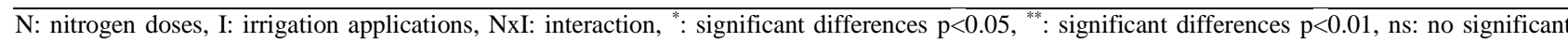
differences.

Table 9. Influence of irrigation treatments and nitrogen doses on Salvia officinalis L. var. Extrakta main essential oil composition in 2012 and $2013(\%)$

\begin{tabular}{|c|c|c|c|c|c|c|c|c|c|c|c|c|c|c|}
\hline \multirow[b]{2}{*}{ 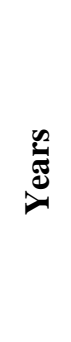 } & \multirow[b]{2}{*}{ 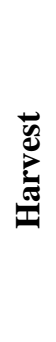 } & \multirow{2}{*}{ 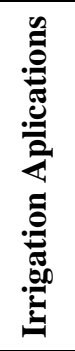 } & \multirow[b]{2}{*}{ 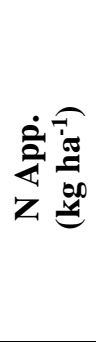 } & \multicolumn{11}{|c|}{ Main Components (\%) } \\
\hline & & & & 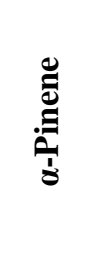 & Uั: & & 苛 & 这 & 兽 & & $\frac{\grave{\Xi}}{\bar{\Xi}}$ & 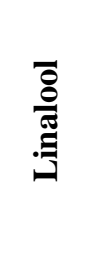 & 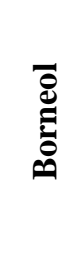 & 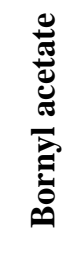 \\
\hline \multirow{12}{*}{ 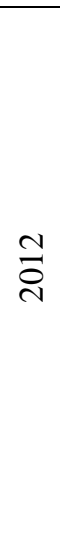 } & \multirow{6}{*}{ I. } & \multirow{2}{*}{$\mathrm{S} 1$} & 0 & - & 1.12 & 8.53 & 0.70 & 1.60 & 32.49 & 8.45 & 22.65 & 3.37 & 6.69 & 1.11 \\
\hline & & & 60 & - & - & 3.71 & 0.52 & 2.09 & 25.09 & 8.21 & 24.81 & 5.31 & 5.03 & 0.89 \\
\hline & & \multirow{2}{*}{ S2 } & 0 & - & - & 4.60 & - & 3.22 & 32.26 & 11.39 & 20.93 & 5.72 & 6.22 & 0.63 \\
\hline & & & 60 & - & - & 6.12 & 0.62 & 1.40 & 29.83 & 12.58 & 21.72 & 2.60 & 2.72 & 0.89 \\
\hline & & \multirow{2}{*}{ S3 } & 0 & 1.07 & 1.00 & 6.80 & 0.75 & 1.01 & 32.04 & 8.11 & 22.91 & 2.70 & 3.89 & - \\
\hline & & & 60 & 0.98 & 1.02 & 9.48 & 0.77 & 1.47 & 34.33 & 7.20 & 15.16 & 4.74 & 6.90 & 1.21 \\
\hline & \multirow{6}{*}{ II. } & \multirow{2}{*}{ S1 } & 0 & - & - & 2.85 & - & 2.75 & 32.55 & 6.07 & 29.60 & 2.46 & 3.91 & 1.10 \\
\hline & & & 60 & - & - & 2.95 & 0.63 & 2.49 & 32.90 & 5.45 & 26.98 & 3.50 & 4.78 & - \\
\hline & & \multirow{2}{*}{ S2 } & 0 & - & - & 3.27 & 0.73 & 1.92 & 33.27 & 5.23 & 22.72 & 4.83 & 4.83 & 1.10 \\
\hline & & & 60 & - & - & 4.16 & 0.64 & 2.15 & 28.31 & 7.44 & 34.59 & 2.68 & 2.54 & 0.93 \\
\hline & & \multirow{2}{*}{ S3 } & 0 & - & - & 3.83 & - & 3.13 & 32.46 & 10.88 & 26.94 & 2.24 & 2.76 & 0.90 \\
\hline & & & 60 & - & 0.43 & 4.02 & 0.71 & 1.92 & 30.00 & 5.63 & 31.36 & 3.87 & 4.52 & 1.11 \\
\hline \multirow{12}{*}{$\stackrel{m}{\stackrel{\sim}{r}}$} & \multirow{6}{*}{ I. } & \multirow{2}{*}{ S1 } & 0 & 0.34 & 0.53 & 5.03 & 0.52 & 1.04 & 31.95 & 7.83 & 21.12 & 4.6 & 2.78 & 1.02 \\
\hline & & & 60 & 0.57 & 0.34 & 6.4 & 0.52 & 1.3 & 28.87 & 7.25 & 24.75 & 7.6 & 5.71 & - \\
\hline & & \multirow{2}{*}{ S2 } & 0 & 1.26 & 1.79 & 5.65 & 0.54 & 1.25 & 32.51 & 5.91 & 22.55 & 4.82 & 3.44 & 1.00 \\
\hline & & & 60 & 0.88 & 1.12 & 6.12 & 0.53 & 1.21 & 31.21 & 6.73 & 23.74 & 5.24 & 2.83 & 0.99 \\
\hline & & \multirow{2}{*}{ S3 } & 0 & 1.34 & 1.84 & 6.36 & 0.61 & 0.70 & 32.37 & 7.63 & 21.31 & 5.02 & 2.72 & 0.79 \\
\hline & & & 60 & - & 0.63 & 5.42 & 0.47 & 1.25 & 29.21 & 6.10 & 21.61 & 4.61 & 3.40 & 0.91 \\
\hline & \multirow{6}{*}{ II. } & \multirow{2}{*}{$\mathrm{S} 1$} & 0 & - & - & 2.45 & 0.68 & 2.06 & 36.17 & 7.28 & 24.86 & 4.71 & 2.64 & 1.14 \\
\hline & & & 60 & - & - & - & - & 4.48 & 14.00 & 5.04 & 18.00 & 6.63 & 9.17 & 0.52 \\
\hline & & \multirow{2}{*}{ S2 } & 0 & - & - & 2.64 & - & 2.64 & 33.25 & 6.48 & 26.81 & 4.50 & 4.17 & 1.27 \\
\hline & & & 60 & - & - & 0.69 & - & 1.38 & 28.57 & 9.01 & 21.59 & 3.79 & 3.61 & 0.27 \\
\hline & & \multirow{2}{*}{ S3 } & 0 & - & - & 1.54 & - & 2.94 & 29.79 & 3.86 & 28.87 & 5.20 & 4.76 & - \\
\hline & & & 60 & - & - & 0.92 & - & 2.02 & 35.76 & 6.82 & 27.31 & 3.79 & 3.17 & 0.94 \\
\hline
\end{tabular}


The antioxidant capacity was not significantly affected by the nitrogen doses and irrigation treatments. The highest value was obtained from 20 days of drying period before harvesting with $60 \mathrm{~kg} \mathrm{ha}^{-1}$ of nitrogen fertilizer in both years (Figure 1.). On the other hand, our results indicated that reducing of irrigation interval caused enhancement of stress severity.
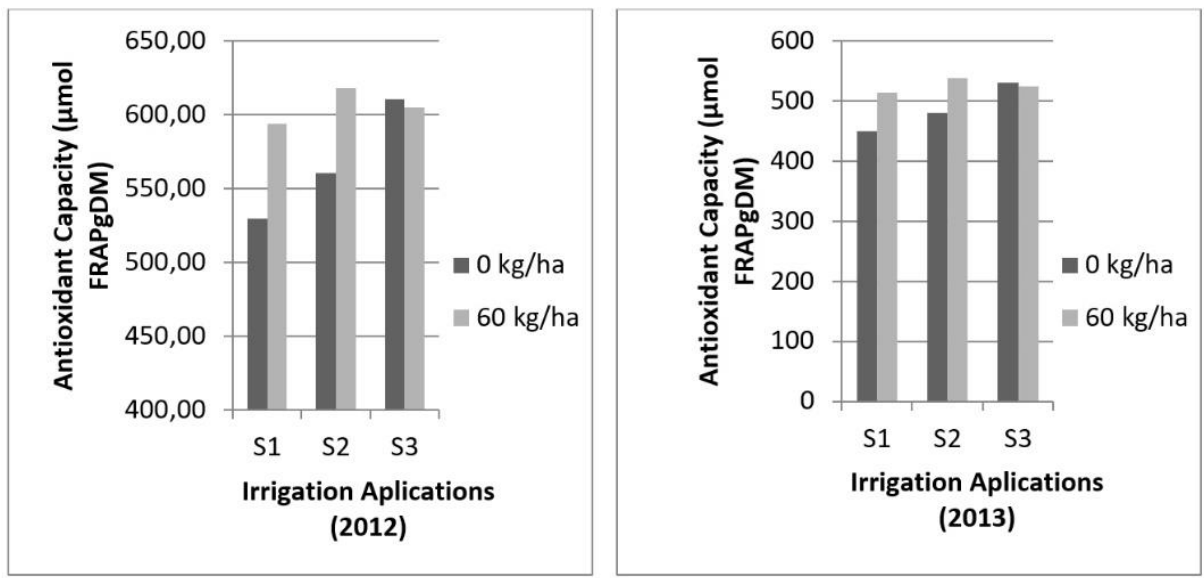

Figure 1. Influence of irrigation treatments and nitrogen doses on antioxidative capacity of Salvia officinalis L. var. Extrakta in 2012 and 2013 .

Salvia officinalis L. plants contain important polyphenols which increase the biosynthesis under water deficit and play significant role in plant resistance (Bettaieb et al. 2011; Manukyan 2011; Pellegrini et al. 2015). Munne-Bosch et al. (2001) reported that antioxidant molecules are responsible for avoiding drought damage in plants. Antioxidant activity (Nakatani, 2003), tend to increase on sage plants in the lack of rainfall during summer season in Mediterranean field conditions. In generally our result were in accordance with literature.

\section{CONCLUSIONS}

The results of the research showed that irrigation water and nitrogen fertilizer are important effects on growth and development characteristics in sage. When water restriction was increased and nitrogen application is not done, the plant growth was decreased as the fresh herbage and drug herbage yield were reduced. One of the most important indicators of the defense mechanism of plants in stress conditions is the synthesis of volatile oils. It could be concluded that decreasing soil moisture might lead to increase in the essential oil amount and antioxidant capacity at the same time.

In conclusion, it is important to determine the effects of limited water use and crop water relations on yield and quality criteria for medicinal and aromatic plant growth when the global warming threat increases and the water resources are reduced. It could be concluded that the yield and quality characteristics of plants with nitrogen fertilizer and the $\mathrm{S} 2$ water application were distinguished.

\section{ACKNOWLEDGEMENTS}

This project was supported by the Scientific Research Project Commission of Ege University, Izmir/Turkey, Project no: 2005-ZRF-053. This article is a part of Doctor of Thesis: The effects of Plant-Water Relationships on Essential Oil Production and Quality in sage (Salvia officinalis L.): Biometrical and Physiological Investigations.

\section{LITERATURE CITED}

Acikgoz, N., E. Ilker, A. Gokcol, 2004. Evaluation of biological research on the computer. E.U. TOTEM No:2 (in Turkish).

Abdelmajeed, N.A., E.N. Danial, H.S. Ayad, 2013. The effect of environmental stress on qualitative and quantitative essential oil of aromatic and medicinal plants. Archives Des Sciences 66(4): 100-120.

Anonim, 2011-2012-2013, Turkish State Meteorological Service in İzmir. Observation Records.

Arabaci O. 1995. Izmir oregano (Origanum onites L.)'s growing technical and quality specifications. Ph.D. Thesis. Graduate School of Natural and Applied Sciences. Ege University. 125 $\mathrm{p}$ (in Turkish).

Atallah, S.S., I. Saliby, R. Baalbaki, and S.N. Talhouk, 2010. Effects of different irrigation. drying and production scenarios on the productivity postharvest quality and economic feasibility of Origanum syriacum a species typically over-collected from the wild in Lebanon. J Sci Food Agric, 91:337-343

Azizi. A., F. Yang, B. Honermeier, 2009. Herbage yield. essential oil content and composition of three oregano (Origanum vulgare L.) populations as affected by soil moisture regimes and nitrogen supply. Industrial Crops and Products. 29:554561.

Baher, Z. F., M. Mirza, M. Ghorbanli, M. R. Rezaii, 2002. The influence of water stress on plant height herbal and essential oil yield and composition in Satureja hortensis L. Flavour Fragr. J. 17: 275-277.

Bahreininejad, B., J. Razmjoo, M. Mirza, 2013. Influence of water stress on morpho-physiological and phytochemical traits in Thymus daenensis. International Journal of Plant Production. ISSN: 1735-6814 (Print). 1735-8043 (Online) 7(1): 151-166.

Benzie, I. F. F. and J. J. Strain, 1999. Ferric reducing antioxidant power assay: direct measure of total antioxidant activity of biological fluids and modified version of simultaneous measurement of total antioxidant power and ascorbic acid concentration. In Methods in Enzymology. 299:15-17. 
Bernotiene, G., R. Butkiene, D. Mockute, 2007. Essential oil composition variability in sage (Salvia officinalis L.). CHEMIJA 18(4):38-43.

Bettaieb, I., N. Zakhama, W.A. Wannes, M. E. Kchouk, B. Marzouk, 2009. Water deficit effects on Salvia officinalis fatty acids and essential oils composition. Scientia Horticulturae 120(2): 271-275

Bettaieb, I., I. Hamrouni-Sellami, S. Bourgou, F. Limam, B. Marzouk, 2011. Drought effects on polyphenol composition and antioxidant activities in aerial parts of Salvia officinalis L. Acta Physiologiae Plantarum - Acta Physiol Plant. 33(4):1103-1111

Ceylan, A., E. Bayram, N. Ozay. H. Otan, A.O. Sarı, M. Polat, 1994. Research on some agronomic and quality characteristics in Salvia officinalis L. (Medicinal Sage) Grown in Different Locations. Congress of Field Crops. Agronomy Reports 1.

Ceylan, A., M.Y. Yurtsever, Ozonsoy, 1979. research on the effect of nitrogen fertilization on agronomical and technological properties of Salvia officinalis L. Journal of Agriculture Faculty of Ege University. 16(3):83-96

Corell , M., M.C. Garcia, J.I. Contreras, M.L. Segura, P. Cermeno, 2012. Effect of water stress on salvia officinalis 1. bioproductivity and its bioelement concentrations Communications. Soil Science and Plant Analysis 43:419-42

Ekren, S., C. Sonmez, E. Ozcakal, Y.S. Kukul Kurttas, E. Bayram, H. Gurgulu, 2012. The effect of different irrigation water levels on yield and quality characteristics of purple basil (Ocimum basilicum L.). Agricultural Water Management. 109:155-161

Ekren, S., C. Sonmez, Y.S. Kukul Kurttas, E. Ozcakal, E. Bayram, 2011. Effect of urrigation on Yield and Quality Characteristics of Medicinal Sage (Salvia officinalis L.) and Anatolian Sage (Salvia fruticosa Mill.) Scientific Research Project Final Report, University of Ege. Project number: 2009-ZRF-026. Bornova/Izmir. pp:36 (in Turkish).

Farahani, H.A., S.A. Valadabadi, J. Daneshian, A.F. Shiranirad, M. A Khalvati,. 2009. Medicinal and aromatic plants farming under drought conditions. Journal of Horticulture and Forestry 1(6):086-092.

Fathi, T., A. Golchin, F. Safikhani, 2012. Effect of drought stress and vermicompost on clary sage. Annals of Biological Research 3(7):3346-3349.

Ipek , A. 2007. Effects of nitrogen fertilization on herbal supplements and certain properties in medical sage $(S$. officinalis L.) lines. Ph.D. Thesis. Graduate School of Natural and Applied Sciences. Ankara University. 100 p (in Turkish).

Khalil, Y.M., M.A.M. Kandil, H.M.F. Swaefy, 2008. Effect of three different compost levels on fennel and salvia growth character and their essential oils. Research Journal of Agriculture and Biological Sciences. 4(1):34-39.

Khazaie, H.R., F. Nadjafi, M. Bannayan, 2008. Effect of irrigation frequency and planting density on herbage biomass and oil production of thyme (Thymus vulgaris) and hyssop (Hyssopus officinalis). Industrial Crops and Products, 27:315-321pp.

Koc , H. 2000. Effects of nitrogen fertilization on herbal supplements and certain properties in medical sage $(S$. officinalis L.) lines, Journal of Agriculture Faculty Gaziosmanpasa University. 17(1): 89-93.
Lier, H. N. 1999. CIGR Handbook of Agricultural Engineering. Land and Water Engineering 1:1-558

Manukyan, A. 2011. Effect of growing factors on productivity and qualilty of lemon catmint. lemon balm and sage under soilless grenhouse production:I drought stress. Medicinal and Aromatic Plant Science and Biotechonology. 5(2):119-125.

Munne-Bosch, S., T. Jubany-Mari, R. Alegre, 2001. Droughtinduced senescence is characterized by a loss of antioxidant defenses in chloroplasts. Plant. Cell and Environment. 24:1319-1327.

Nakatani, N., 2003. Biologically functional constituents of species and herbs. J. Japanase Soc. Nutr. Food Sci. 56 (6),389395.

Oktay Koc, P. 2006. Effect of Nitrogen and Sulphur Sage (S. officinalis L.) on plant yield and certain quality parameters, Master Thesis. Graduate School of Natural and Applied Sciences. Ankara University. $48 \mathrm{p}$ (in Turkish).

Ozturk , A., A. Unlukara, A. Ipek, B. Gurbuz, 2004. Effects of Salt Stress And Water Deficit On Plant Growth And Essential Oil Content Of Lemon Balm (Melissa officinalis L.) Pak. J. Bot. 36(4):787-792.

Pellegrini, E., A. Francini, G. Lorenzini, C. Nali, 2015. Ecophysiological and antioxidant traits of Salvia officinalis under ozone stress. Environ. Sci. Pollut. Res. 22:1308313093.

Porte, A., R.L.O. Godoy, L.H. Maia-Prtoe, 2013. Chemical composition of sage (Salvia officinalis L.) essential oil from the Rio de Janeiro State (Brazil). Rev. Bras. Pl. Med., Campinas 15(3):438-441.

Putievsky, E., U. Ravid, N. Dudai, 1986. The Influence of season and harvest frequency on essential oil and herbal yields from a pure clone of sage (Salvia officinalis) grown under cultivated conditions. Journal of Natural Proaducts. 49(2): 326-329.

Said-Al Ahl, H., M.S. Hussein, A.S.H. Gendy, K.G. Tkachenko, 2015. Quality of sage (Salvia officinalis L.) essential oil grown in Egypt. Internat. J. Plant Sci. Ecol. 1(4):119-123.

Steel, R.G.D. and J.H. Torrie, 1980. Principles and procedures of statistics. McGaw-Hill book Company. Inc. N.Y.

Sonmez, C., E. Bayram, 2009. Determination of some agronomic and technological properties in different originated of rosemary (Rosmarinus officinalis). Turkish VIII. Congress of Field Crops. Agronomy Reports 1. 19-22 October, Hatay, p:50-54 (in Turkish).

Tosun, A., S. Khan, Y.S. Kim, A. Calin-Sanchez, X. Hysenaj, A.A. Carbonell-Barrachina, 2014. Essential oil composition and anti-inflammatory activity of Salvia officinalis L. (Lamiaceae) in murin macrophages. Tropical Journal of Pharmaceutical Research 13(6):937-942.

Wichtl, M. 1971. Die Pharmakognostichemische Analys, Band 2., Frankfurt/M.

Zervoudakis, G., G. Salahas, G. Kaspiris, E. Konstantopoulou , 2012. Influence of light intensity on growth and physiological characteristics of common sage (Salvia officinalis L.). Braz. arch. biol. technol. 55 (1): 89-95 